Original Research Paper

\title{
Regulation of Gene Expression by $\beta$-Glucans
}

\author{
${ }^{1}$ Mary O. Huff and ${ }^{2}$ Carolyn M. Klinge \\ ${ }^{I}$ Department of Biology, Bellarmine University, Louisville, KY 40205, USA \\ ${ }^{2}$ Department of Biochemistry and Molecular Genetics, \\ University of Louisville School of Medicine, Louisville, KY 40292, USA
}

\author{
Article history \\ Received: 15-11-2016 \\ Revised: 12-01-2017 \\ Accepted: 29-03-2017 \\ Corresponding Authors: \\ Mary O. Huff \\ Department of Biology, \\ Bellarmine University, \\ Louisville, KY 40205, USA \\ Tell: 502-272-8495 \\ Email: mhuff@bellarmine.edu \\ Carolyn M. Klinge \\ Department of Biochemistry \\ and Molecular Genetics, \\ University of Louisville School \\ of Medicine, Louisville, KY \\ 40292, USA \\ Tell: 502-852-3668 \\ Email: Carolyn.klinge@louisville.edu
}

\section{Introduction}

$\beta$-D-glucans are diverse polysaccharides derived from plant cell walls, fungi and bacteria composed of Dglucose monomers linked by (1-3) $\beta$-glycosidic bonds and variable amounts of (1-6) and (1-4) branches. $\beta$-D-glucans are considered to be "biological response modifiers" because they exhibit antibacterial, antiviral, anticoagulatory, anti-tumoral immunomodulatory and woundhealing activities (Bohn and BeMiller, 1995). In addition, $\beta$-D-glucans stimulate the immune system against infectious pathogens and cancer (Saraswat-Ohri et al., 2011; Chan et al., 2009; Aleem, 2013). When ingested in plant materials, $\beta$-glucans are absorbed in the small intestine, internalized and fragmented by macrophages and subsequently carried to the spleen, lymph nodes and bone marrow (Chan et al., 2009). Here it is believed that the soluble $\beta$-glucan fragments are released and taken up by circulating granulocytes, monocytes and dendritic cells while insoluble fragments induce a cellular response by binding to cell surface receptors. Several types of $\beta$-glucan receptors have been identified including several immune receptors, e.g., Dectin-1, Complement Receptor (CR3), CD11b/CD18, Mac-1, $\mathrm{aMb}$ integrin (Ross, 2000), Scavenger Receptors (SR),
Lactosylceramide (LacCer) and toll-like receptors, e.g., TLR-2/6 and trigger responses in macrophages, neutrophils, monocytes, natural killer cells and dendritic cells in vitro (Chan et al., 2009; Kim et al., 2011; Legentil et al., 2015). $\beta$-glucans also bind to L-Ficolin (Legentil et al., 2015). Through this interaction with plasma membrane receptors, $\beta$-glucans potentiate intracellular signaling pathways that ultimately activate transcription factors such as $\mathrm{NF \kappa B}$ resulting in both innate and adaptive immune responses (Li et al., 2010).

In addition to immunomodulatory activity, $\beta$-glucans have been reported to have direct anti-cancer activity in vitro. A water-soluble $\beta$-glucan extract from the mycelia of Poriacocos inhibited the viability (MTT assay) of MCF-7 human breast cancer cells with an $\mathrm{IC}_{50}$ of $400 \mu \mathrm{g}$ $\mathrm{mL}^{-1}$ and decreased cyclin $\mathrm{D} 1$ and cyclin $\mathrm{E}$ protein expression (Zhang et al., 2006). We reported that a purified preparation of $\beta$-D-glucan (from barley) dissolved in DMSO - but not water- inhibited the growth of estrogen receptor $\alpha(\mathrm{ER} \alpha)+\mathrm{MCF}-7$ cells with an $\mathrm{IC}_{50}$ of $\sim 164 \pm 12 \mu \mathrm{g} \mathrm{mL} \mathrm{m}^{-1}$ compared to normal breast epithelial (ER $\alpha-)$ MCF-10A cells, $\mathrm{IC}_{50} \sim 464 \mu \mathrm{g} \mathrm{mL}$ (Jafaar et al., 2014). $\beta$-glucan inhibited the estradiol ( $\left.\mathrm{E}_{2}\right)$ independent, tamoxifen (TAM) and fulvestrant-resistant, $\mathrm{ER} \alpha+\mathrm{LCC} 9$ and LY2 cells (derived from MCF-7 cells) 
with $\mathrm{IC}_{50}$ values of $4.6 \pm 0.3$ and $24.2 \pm 1.4 \mu \mathrm{g} \mathrm{mL}{ }^{-1}$, respectively (Jafaar et al., 2014). In contrast, the "triple negative/basal-like" MDA-MB-231 breast cancer cells were not growth inhibited by $\beta$-glucan (Jafaar et al., 2014). Conversely, aqueous-soluble $\beta$-glucans reportedly had no direct cytotoxic effects on a panel of common cancer cell lines including blastoma, carcinoma and sarcoma cells (Chan et al., 2009).

There are many studies of $\beta$-glucans purified from the cell walls of yeast, fungi and plants as immunomodulators that increase the levels of proinflammatory cytokines, chemokines and cell adhesion molecules (Novak and Vetvicka, 2008). We will review immunomodulatory genes regulated by $\beta$-glucans in human and mouse cells. In addition, we reviewed the literature to identify additional genes increased or inhibited by glucan treatment of cells in vitro. We summarize the downstream effects of these transcriptional changes and how they inform the mechanisms by which glucans act in various cell types.

\section{Glucans Increase Gene Transcription in Human Cancer Cells and Immortalized Normal Cells}

A number of reports have examined the effect of $\beta$ glucan on transcription in human and murine immune cells with a few studies examining the activity of glucans in human cancer cells. Table 1 summarizes those genes that were transcriptionally induced by $\beta$ glucan in the cells examined. First, we will review the results in human cells.

\section{$\beta$-Glucan in Breast Cancer Cells}

In our lab, it was shown that a purified $\beta$-D-glucan isolated from barley and dissolved in DMSO, but not water, inhibited cell viability in two human breast cancer cells lines: MCF-7 and LCC9, an endocrine-resistant (estradiol, tamoxifen and fulvestrant) cell line derived from MCF-7. Using two concentrations of $\beta$-D-glucan, we examined the expression of a set of genes implicated in breast cancer in both cell lines using PCR array analysis.

Table 1. Genes upregulated by glucan in cell systems. The concentration, form and source of $\beta$-glucan used in the experiment is indicated. The comments include information about the genes regulated taken from the references cited and the GeneCards human gene database http://www.genecards.org/ LMW = low molecular weight

\begin{tabular}{lll}
\hline Gene (s) & Cell system & $\beta$-glucan \\
\hline BIRC5, BRCA1, BRCA2, & MCF-7 human breast & 10 or $50 \mu \mathrm{g} \mathrm{mL} \mathrm{m}^{-1} \beta$-D \\
CCNA1, PGR, RASSF1 & cancer cells & glucan purified from barley \\
& & and purchased from Sigma \\
& & (cat. No. G6513, purity \\
& $\sim 97 \%$ ), dissolved in DMSO
\end{tabular}

(Jafaar et al., 2014)

$$
\begin{aligned}
& \text { Comments } \\
& \text { BIRC5 is anti-apoptotic;BRCA1 } \\
& \text { and BRCA2 are involved in DNA } \\
& \text { repair, Cyclin A1 }(C C N A 1) \\
& \text { regulates cell cycle progression, } \\
& \text { progesterone receptor }(P G R) \text { is a } \\
& \text { breast cancer differentiation } \\
& \text { marker, RASSF1 (NORE2A) is a } \\
& \text { scaffolding protein that functions } \\
& \text { as a tumor suppressor }
\end{aligned}
$$

\begin{tabular}{|c|c|c|c|c|}
\hline CTSD, PTGS2 & $\begin{array}{l}\text { MCF-7 human breast } \\
\text { cancer cells }\end{array}$ & $10 \mu \mathrm{g} \mathrm{mL}^{-1} \beta$-D glucan & (Jafaar et al., 2014) & $\begin{array}{l}\text { Cathepsin D }(C T S D) \text { is an acid } \\
\text { protease; COX-2 (PTGS2) } \\
\text { increases pro-inflammatory } \\
\text { cytokines }\end{array}$ \\
\hline$M K 167$ & $\begin{array}{l}\text { MCF-7 human breast } \\
\text { cancer cells }\end{array}$ & $50 \mu \mathrm{g} \mathrm{mL}^{-1} \beta$-D glucan & (Jafaar et al., 2014) & $\begin{array}{l}\mathrm{Ki}-67 \text { is a marker of cell } \\
\text { proliferation }\end{array}$ \\
\hline $\begin{array}{l}E G F, G L I 1, H I C, I G F 1, \\
I G F B P 3, P T G S 2\end{array}$ & $\begin{array}{l}\text { LCC } 9 \text { endocrine-resistant } \\
\text { human breast cancer cells }\end{array}$ & 10 or $50 \mu \mathrm{g} \mathrm{mL}^{-1} \beta$-D glucan & (Jafaar et al., 2014) & $\begin{array}{l}\text { GLI1 is a zinc finger transcription } \\
\text { factor; HIC is the gene } M D F I C \text { is } \\
\text { a transcriptional regulator }\end{array}$ \\
\hline TP53, $C D K N 1 B$ & $\begin{array}{l}\text { MCF-7 human breast } \\
\text { cancer cells }\end{array}$ & $\begin{array}{l}\text { Fungal } \beta \text {-glucan } \\
\text { (Botryosphaeran, BOT) was } \\
\text { produced by } B \text {. rhodina } \\
\text { MAMB- } 05 \text { grown on nutrient } \\
\text { medium containing glucose } \\
\left(\mathrm{BOT}_{\mathrm{GLC}}\right) \text { and fructose }\left(\mathrm{BOT}_{F R U}\right) \\
\text { Cells were treated with } \\
100 \mu \mathrm{g} \mathrm{mL}^{-1} \text { for } 48 \mathrm{~h}\end{array}$ & (Queiroz et al., 2015) & $\begin{array}{l}\text { P53 and P27 are involved in cell } \\
\text { cycle arrest }\end{array}$ \\
\hline CD86 & $\begin{array}{l}\text { Dectin-1(+)CR3(-) human } \\
\text { Burkitt (B-cell) lymphoma } \\
\text { cell lines (Daudi and Raji) }\end{array}$ & $\begin{array}{l}\text { Aqueous underivatized } \beta \\
\text { glucan from Saccharomyces } \\
\text { cerevisiae }\left(1 \mu \mathrm{g} \mathrm{mL}^{-1}\right) \text { for } \\
\text { Raji cells and } 0.1 \mu \mathrm{g} / \mathrm{ml} \text { for } \\
\text { Daudi cells }\end{array}$ & (Harnack et al., 2011) & $\begin{array}{l}\text { Maturation marker-measured cell } \\
\text { surface expression by flow } \\
\text { cytometry. Observed peak } \\
\text { increase at } 48 \mathrm{~h} \text { tx. Both cell } \\
\text { lines express dectin-1, the major } \\
\beta \text {-glucan receptor. }\end{array}$ \\
\hline HSP70 protein, $M U C 1$ & $\begin{array}{l}\text { Human gastric carcinoma } \\
\text { cells }\end{array}$ & $\begin{array}{l}\text { LMW } \beta \text {-glucan purified from } \\
\text { conditioned medium of } \\
\text { Aureobasidium pullulans GM- } \\
\text { NH-1A1 with } \sim 70 \% \beta \text {-(1-6) } \\
\text { branches } 100 \mu \mathrm{gL}^{-1}\end{array}$ & (Tanaka et al., 2011) & $\begin{array}{l}\text { MUC1 is mucin } 1 \text {, a } \\
\text { transmembrane protein. }\end{array}$ \\
\hline
\end{tabular}




\begin{tabular}{|c|c|c|c|c|}
\hline $\begin{array}{l}\text { PKC, CXCL8 (IL-8 } \\
\text { gene), CDC42, BBC3 } \\
\text { (PUMA) } \\
\text { IL-10, IL-12, IL-23 } \\
\text { transcripts }\end{array}$ & $\begin{array}{l}\text { Detroit-573 human } \\
\text { fibroblasts and Ha } \\
\text { Cat human keratinocytes } \\
\text { Human monocyte-derived } \\
\text { Dendritic Cells (DCs) } \\
\text { from healthy donors }\end{array}$ & $\begin{array}{l}6 \text { different synthetic glucans- } \\
\text { no concentrations or treatment } \\
\text { times indicated } \\
\text { zymosan ( } \beta \text {-glucan from } \\
\text { Saccharomyces cerevisiae } \\
\text { (InvivoGen) } 10 \text { and } \\
200 \mu \mathrm{g} \mathrm{mL}^{-1}\end{array}$ & $\begin{array}{l}\text { (Vetvicka et al., 2011) } \\
\text { (Gerosa et al., 2008) }\end{array}$ & $\begin{array}{l}\text { Regulators of cell growth and } \\
\text { PUMA is a BCL-2 pro- } \\
\text { apoptotic protein } \\
\text { reviewed in (Lyakh } \text { et al., } \\
2008 \text { ) }\end{array}$ \\
\hline IL23A, PTGS2 & $\begin{array}{l}\text { Human monocyte-derived } \\
\text { DCs from healthy donors }\end{array}$ & $\begin{array}{l}\beta(1,3) \text {-glucan Zymosan from } \\
\text { Saccharomyces cerevisiae } \\
\text { (Sigma) } 1 \mathrm{mg} \mathrm{mL}^{-1}, 4 \mathrm{~h}\end{array}$ & (Rodríguez et al., 2014) & $\begin{array}{l}\beta \text {-glucan activates the Unfolded } \\
\text { Protein Response in DCs }\end{array}$ \\
\hline 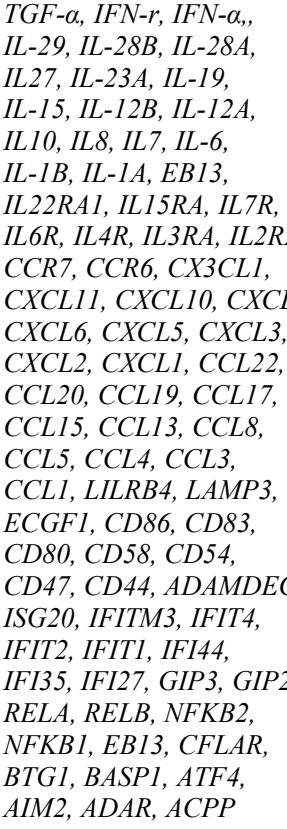 & $\begin{array}{l}\text { Human monocyte-derived } \\
\text { DCs from healthy donors }\end{array}$ & $\begin{array}{l}\text { PS-G, a branched }(1 \rightarrow 6)-\beta \text { - } \\
\text { d-glucan) purified from } \\
\text { Ganoderma lucidum } \\
10 \mu \mathrm{g} \mathrm{mL} \mathrm{m}^{-1} \text { for } 16 \mathrm{~h}\end{array}$ & (Lin et al., 2006) & AffymetrixGeneChip microarray \\
\hline $\begin{array}{l}\text { Examples include } \\
\text { RPS18, EGR1, NFKBID, } \\
\text { NFATCA1, IFNB1, } \\
\text { S100A9, S100A8, } \\
\text { GAPDH, TGFA, MMP2, } \\
\text { CYP7B1, IL12B, IL12A, } \\
\text { EB13, ITGB8, IL27, IL15 } \\
\text { CD38, CD80, CCR7, } \\
\text { STAT3, IRF1, TNF, } \\
\text { CCL4, IL10,IL20, IL23, } \\
\text { NFKB1A, NFKBIZ, } \\
\text { PTGS2, TLR2, SOD2, } \\
\text { NFKB1, IL6, IL1B, IL9 }\end{array}$ & $\begin{array}{l}\text { Human monocyte-derived } \\
\text { DCs from healthy donors }\end{array}$ & $\begin{array}{l}\beta \text {-glucan from baker's yeast } \\
\text { (Sigma-Aldrich) } 10 \mu \mathrm{g} \mathrm{mL}^{-1} \\
4 \text { or } 12 \mathrm{~h}\end{array}$ & (Cardone et al., 2014) & $\begin{array}{l}\text { Agilent- } 014850 \text { Whole Human } \\
\text { Genome Microarray } 4 \times 44 \\
\text { K G4112F } \\
\text { GEO accession number } \\
\text { GSE42189. }\end{array}$ \\
\hline $\begin{array}{l}\text { TNF- } \alpha, I L 6, I L 8, I L 12, \\
I L 18\end{array}$ & $\begin{array}{l}\text { Human B lymphocytes } \\
\text { isolated from healthy } \\
\text { donors }\end{array}$ & $\begin{array}{l}\text { Curdlan (Sigma-Aldrich) } \\
100 \mathrm{ug} \mathrm{mL}^{-1} \text { for } 24 \mathrm{~h}\end{array}$ & (Ali et al., 2015) & $\begin{array}{l}\text { IL-8 expression was shown to } \\
\text { involve Dectin-1, SYK, MAPKs } \\
\text { and transcription factors AP-1 } \\
\text { and NF-kB }\end{array}$ \\
\hline GITRL protein & Murine DCs & $\begin{array}{l}\text { whole } \beta \text { glucan particles from } \\
\text { S. cerevisiae treated for } 48 \mathrm{~h} \\
\left(100 \mu \mathrm{g} \mathrm{mL}^{-1}\right)\end{array}$ & (Tian et al., 2012) & $\begin{array}{l}\text { TNFSF } 18 \text { is the gene for GITRL, } \\
\text { a cytokine in the TNF ligand } \\
\text { family }\end{array}$ \\
\hline $\begin{array}{l}D d x 58, M d a 5, \text { IL- } 1 \beta \text {, } \\
\text { IL- } 6, \text { TNF } \alpha, \text { GM-CSF } \\
\text { and G-CSF }\end{array}$ & $\begin{array}{l}\text { Murine macrophage- } \\
\text { derived RAW264.7 cells }\end{array}$ & $\begin{array}{l}\text { Aureobasidium pullulans } \\
\text { produced purified } \beta(1->3), \\
\left.(1->6) \text { D glucan } 100 \mu \mathrm{gL} \mathrm{mL}^{-1}\right) \\
\text { time course experiments: } 3-24 \mathrm{~h}\end{array}$ & (Muramatsu et al., 2012) & $\begin{array}{l}D d x 58 \text { is RIG- } 1 \text { (retinoic acid- } \\
\text { inducible gene-I). MDA5 is an } \\
\text { intracellular pattern recognition } \\
\text { molecule }\end{array}$ \\
\hline $\begin{array}{l}U M P S=\text { Uridine } \\
\text { Monophosphate } \\
\text { synthetase, }\end{array}$ & $\begin{array}{l}\text { Human KB cells (subclone } \\
\text { of HeLa cells) grown as a } \\
\text { tumor xenograft in female } \\
\text { athymic mice }\end{array}$ & $\begin{array}{l}\text { lentinan purified from } \\
\text { Lentinus edodes (Shiitake } \\
\text { mushroom) Dose (ip injection): } \\
0.1 \mathrm{mg} / \mathrm{kg} / \text { day } 2 \mathrm{X} / \text { week for } \\
3 \text { weeks }\end{array}$ & (Harada et al., 2010) & $\begin{array}{l}\text { measured by RT-PCR in the } \\
\text { microdissected tumor; } \\
\text { UMPS is also called Orotate } \\
\text { Phosphoribosyl Transferase } \\
\text { (OPRT) }\end{array}$ \\
\hline$I F N-Y$ & Lungs of normal mice & $\begin{array}{l}\text { Antrodia camphorate beta- } \\
\text { glucan; mice were fed beta } \\
\text { glucan daily for } 12 \text { days }\end{array}$ & (Wang et al., 2015) & \\
\hline
\end{tabular}


$\beta$-D-glucan increased the expression of 9 genes in MCF7 human breast cancer cells and 5 genes in LCC9 breast cancer cells (Jafaar et al., 2014). These genes are summarized in Table 1. Overall, depending on the concentration of $\beta$-D-glucan, we observed that $\beta$-Dglucan increased the expression of genes involved in proliferation (MK167 (Ki-67), CCNA1 (cyclin A1) and BIRC5), invasion (CTSD (cathepsin D)), inflammation (PTGS2 (COX-2)), differentiation (PGR (progesterone receptor)), tumor suppression (RASSF1) and DNA repair (BRCA1, BRCA2). Surprisingly, a set of different genes were upregulated by $\beta$-D-glucan in the endocrine-resistant (tamoxifen and fulvestrant) LCC9 cells with the exception of the common increase in $P T G S 2$. These genes were involved in proliferation (EGF, IGF1, IGFBP3) and transcription (GL1). The mechanism for this difference is unknown, although LCC9 cells have higher NFKB expression/activity than MCF-7 (Litchfield et al., 2014).

More recent studies reported that two preparations of fungal $\beta$-glucans inhibited MCF-7 cell viability, stimulated apoptosis and ROS production and increased necrosis (Queiroz et al., 2015). $\mathrm{BOT}_{\mathrm{GLC}}$ and $\mathrm{BOT}_{\mathrm{FRU}}$ $\left(100 \mu \mathrm{g} \mathrm{mL}^{-1}\right.$, Table 1) increased the mRNA and protein expression of p53 (TP53) and p27 (CDKN1B) after $48 \mathrm{~h}$ of treatment (Queiroz et al., 2015). The authors reported that $\mathrm{BOT}_{\mathrm{GLC}}$ activated AMPK, increased FOXO3a protein and reduced phospho-FOXO3a, suggesting that stimulation of FOXO3a transcriptional activity is the mechanism by which cell arrest is achieved. This was supported with the observation that treatment with these $\beta$-glucans resulted in an increase in p53 and p27 transcription (Queiroz et al., 2015).

\section{$\beta$-Glucan Regulates Protein and Gene Expression in Gastric Cancer Cells and other Human Cell Lines}

Treatment of human gastric carcinoma cells with $\beta$ glucan increased the expression of HSP70 protein (HSPA1A gene) and MUC1 transcript levels (mucin-1, a transmembrane protein) - both of which are protective factors in the gastric mucosa (Tanaka et al., 2011). We note that the primary focus of this study was to examine the protective effects of $\beta$-glucans on gastric lesions in mice with confirmation of HSP70 and MUC1 in gastric cancer cells.

Synthetic glucans increased expression of $P K C$ (protein kinase C), CXCL8 (IL-8), CDC-42 and PUMA $(B B C 3)$ transcripts in human Detroit-573 fibroblasts and $\mathrm{HaCaT}$ keratinocytes as measured by non-quantitative PCR (Vetvicka et al., 2011). These genes are regulators of cell growth and PUMA is a BCL-2 pro-apoptotic protein.

\section{Microarray Analysis in Human Monocyte-Derived Dendritic Cells}

Gene array profiling of human monocyte-derived Dendritic Cells (DCs) treated with a purified extract of
Polysaccharide (PS-G, a branched $(1 \rightarrow 6)-\beta$-d-glucan) from Ganoderma lucidum, a Chinese medicinal mushroom, identified 3477 (17\%) probe sets upregulated (2-fold) and $4418(19 \%)$ probe sets downregulated (2fold) after $16 \mathrm{~h}$ of treatment (Lin et al., 2006). The identity of genes included in the text of that manuscript (Lin et al., 2006) are shown on Table 1 and 2. Significant increases in transcript levels were observed for a number of cytokines (IL-12A, IL-12B, IL-23A, IL-27 and EBI2; also known as IL-27B), chemokines and chemokine receptors (CCL20, CCL19, CCL5, CXCL10, CXCL11 and CCR7) and cell surface proteins (CD80, CD83 and CD86). The authors also noted that an increase in transcripts for $N F K B 1$, $N B K B 2, R E L A, R E L B$ and MAPK11which support the model that $\beta$-glucans activate human dendritic cells through the NFкB and p38 MAPK pathways. Further, the authors suggested that the increase in CCL20, IL-27, IL23A, IL-12A and IL-12B transcripts after PS-G treatment of human DCs may play a role in the anti-tumor activity of $\beta$-glucans (Lin et al., 2006).

A more recent microarray profiling of human monocyte-derived DCs treated with $\beta$-D glucan $(10 \mu \mathrm{g}$ $\mathrm{mL}^{-1}$ ) for 4 or $12 \mathrm{~h}$ identified $\sim 1500$ genes that were either inhibited (38\%) or induced (62\%) (Cardone et al., 2014). The $\beta$-D glucan-regulated genes were divided into 6 groups: (1) Early-inhibited genes (4-6 h after activation); (2) genes inhibited similarly at both early and late times (early-late-inhibited genes); (3) lateinhibited genes; (4) early-induced genes; (5) genes induced similarly at both early and late times (earlylate-induced genes; and (6) late-induced genes (12 h after activation). Gene ontology analysis indicated that the early induced genes were likely involved in apoptosis or stress and antiviral responses, e.g., IFNB1, NFKBID, NFATC1, TNF, proIL1 $\beta, N F K B I Z$ and that these genes were potentially regulated by Interferon Regulatory Factors (IRFs). The early-induced genes were identified to be involved in chemotaxis, IL-1 production and $\mathrm{NF} \kappa \mathrm{B}$ or STAT signaling and were predicted to be regulated by NFKB and IRFs. The lateinduced genes included chemokines, cytokines and other factors involved in DC activation and proliferation, e.g., IL6, I10, IL12B, IL20, IL23A, IL1F9, $C S F 7, C S F 3$; and were predicted to be regulated by NFkB, IRFs, AP1, STATs and CEBPs. The authors demonstrated that $\beta$-glucan stimulates IL-1 expression which once processed by the caspase/inflammasome pathway acts in an autocrine fashion to stimulate the expression of the late-induced cytokines at the

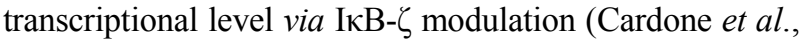
2014). Further, the authors reported that $\beta$-glucan also promoted an IFN-I gene signature consistent with the reported induction of IFN-I in response to fungi via Dectin-1 signaling. These data demonstrated that IL-1 and IFN- $\gamma$ differentially regulate the $\beta$-glucan-induced Th responses in human DCs. 
Table 2. Genes down-regulated by glucan. The cell type and concentration and form of $\beta$-glucan used in these studies is indicated. The comments include information about the genes regulated taken from the references cited and from the Gene Cards human gene database http://www.genecards.org/

\begin{tabular}{|c|c|c|c|}
\hline Gene & Cell system & $\beta$-glucan & Ref. \\
\hline $\begin{array}{l}\text { Measured Cyclin D1 } \\
\text { and Cyclin E proteins } \\
\text { by flow cytometry }\end{array}$ & $\begin{array}{l}\text { MCF-7 human breast } \\
\text { cancer cells }\end{array}$ & $\begin{array}{l}400 \mu \mathrm{g} \mathrm{mL}^{-1} \text { PCM3-II, a water- } \\
\text { soluble } \beta \text {-glucan purified } \\
\text { from the mycelia of } \\
\text { Poriacocos, } 48 \mathrm{~h} \text { treatment }\end{array}$ & (Zhang et al., 2006) \\
\hline $\begin{array}{l}C D K N 1 C, P L A U, \\
R A R B\end{array}$ & $\begin{array}{l}\text { MCF-7 human breast } \\
\text { cancer cells }\end{array}$ & $\begin{array}{l}10,50 \mu \mathrm{g} \mathrm{mL}^{-1} \beta \text {-D glucan; } \\
24 \mathrm{~h}\end{array}$ & (Jafaar et al., 2014) \\
\hline $\begin{array}{l}C T N N B 1, I G F B P 2, \\
\text { SLIT2 }\end{array}$ & $\begin{array}{l}\text { MCF-7 human breast } \\
\text { cancer cells }\end{array}$ & $50 \mu \mathrm{g} \mathrm{mL}^{-1} \beta$-D glucan; $24 \mathrm{~h}$ & (Jafaar et al., 2014) \\
\hline MUC1, SNAI2 & $\begin{array}{l}\text { MCF-7 human breast } \\
\text { cancer cells }\end{array}$ & $10 \mu \mathrm{g} \mathrm{mL}^{-1} \beta$-D glucan; $24 \mathrm{~h}$ & (Jafaar et al., 2014) \\
\hline
\end{tabular}
comments

\section{Cell cycle regulators}

CDKN1C is a negative regulator of cell proliferation; Plasminogen Activator, Urokinase (PLAU) is a serine protease, Retinoic Acid Receptor $\beta(R A R B)$ is a differentiation maker $C T N N B 1$ is $\beta$ catenin; IGFBP2 is Insulin Like Growth Factor Binding Protein 2; SLIT2 is a secreted glycoprotein involved in cell migration MUC1 is a transmembrane protein that is cleaved at its intracellular domain interacts with $\mathrm{ER} \alpha$ and contributed to endocrine-resistance (Kufe, 2013); SNAI2 is the protein LUG which is a transcriptional repressor

ADAM23 is a membrane protein that acts as a tumor suppressor; $\mathrm{CDH1}$ is Cadherin 13; CDH13 is Cyclin-Dependent Kinase Inhibitor $1 \mathrm{C}$ - a negative regulator of cell proliferation; CTNNB1 is $\beta$-catenin

ERCC5 HepG2 cells

Identified 61 Splenic MDSC from downregulated miRNAs tumor-bearing mice -focused on $m m u$-miR-9 $C R E B m R N A$ and protein

\author{
A $\beta$-glucan-containing \\ polysaccharide complex \\ purified from Agaricusblazei \\ Murill mushroom of Brazilian \\ origin by aqueous extraction \\ (Gonzaga et al., 2005) \\ $50 \mu \mathrm{g} \mathrm{mL}^{-1}$ for $6 \mathrm{~h}$ \\ $100 \mathrm{ug} \mathrm{mL}^{-1}$ for $24 \mathrm{~h}$; whole \\ $\beta$-glucan particles from \\ S. Cerevisiae
}

(da Silva et al., 2013)

(Tian et al., 2015) ERCC5 is involved in excision repair following DNA damage

miRNA microarray assay
$T S, D P D$
Human KB cells (subclone lentinan purified from of HeLa cells) grown as a Lentinus edodes (Shiitake tumor xenograft in female mushroom) Dose (ip injection) athymic mice $0.1 \mathrm{mg} / \mathrm{kg} /$ day $2 \mathrm{X} /$ week for 3 weeks
ARHGDIB, ATM, Human monocyte-derived PS-G, a branched $(1 \rightarrow 6)-\beta$ - DCs from healthy donors
CEBPA, CSFIR, CST F13A1, ITGAM, ITGB2, VCL
Ptgs2 (Cox2 gene) Lungs of normal C57BL/6JNarl mice Ganoderma lucidum $10 \mu \mathrm{g} / \mathrm{ml}$ for $16 \mathrm{~h}$ Antrodia camphorate beta- glucan; mice were fed beta glucan daily for 12 days

(Harada et al., 2010)

(Lin et al., 2006) GEO accession number GSE67578; Identified Runx1, a transcription factor involved in differentiation of MDSCs, as a direct, bona fide target of miR-9. CREB, transcription factor, suppressed miR-9 transcription. measured by microdissection and RT-PCR;

Thymidylate Synthase (TS)

Dihydropyrimidine Dehydrogenase (DPD)

Affymetrix GeneChip microarray

\section{$\beta$-Glucan Stimulates IL23A and IL-10 Transcription But not IL-12 in Human Dendritic Cells}

In a study designed to determine the effect of $\beta$ glucan on the production of IL12 and IL23 in human dendritic cells, high and low concentrations of purified $\beta$-glucan (10 versus $200 \mu \mathrm{g} \mathrm{mL}^{-1}$ zymosan) were shown to induce transcription of IL-23 and IL10, which was enhanced when cells were simultaneously treated with R848 (a Toll-like receptor 
7 and 8 agonist) or with Pam2C (TLR2 ligand) (Gerosa et al., 2008). IFN- $\gamma$ priming inhibited zymosan-stimulated IL-23 transcription (Gerosa et al., 2008). In contrast, transcription of IL-12 was not induced by zymosan alone. Instead, expression of IL12 was observed only when cells were first primed with IFN- $\gamma$ and treated with low concentrations of zymosan and R848. Based on these observations, the authors concluded that the differential expression of IL-23 and IL-12 is dependent on the specific PPRs (pattern recognition receptors) that are activated by different microorganisms. Specifically, TLR2 is able to differentially regulate the expression of these two cytokines which allows DCs to respond appropriately to different pathogens (Gerosa et al., 2008).

In a more recent study, Rodríguez et al. (2014) showed that selective upregulation of IL-23 by zymosan (1 $\left.\mathrm{mg} \mathrm{mL}^{-1}\right)$ involves activating transcription Factor 2 (ATF2) in addition to NFאB which stimulates both IL-23 and IL-10. In these studies, the authors suggest that zymosan interaction with dectin-1 activates PKA-MEK-ERK and PKC signaling leading to activation of ATF2 and coordinates with TLR2 signaling to activate NFKB. ATF2 and NFKB stimulate IL23A transcription (Rodríguez et al., 2014). While zymogen and two other insoluble $\beta$-glucans (curdlan- and pustulancontaining latex beads) resulted in the disappearance of the Endoplasmic Reticulum Stress Response (ERS) transcription factors $\mathrm{CHOP}$ and XBP-1 from the nucleus of human DCs and macrophages, there was no evidence that CHOP is involved directly in IL-23 induced expression (Rodríguez et al., 2014).

\section{$\beta$-Glucans Induce Cytokine Production in Human B Lymphocytes}

While most studies have focused on the activation of gene expression in DCs, a recent report demonstrated that purified $\beta$-glucan (curdlan) induces expression of several cytokines including TNF $\alpha$, IL-6 andIL-8 in human B lymphocytes at both the mRNA and protein level (Ali et al., 2015). Activation of IL-8 was shown to be mediated through the Dectin-1 receptor and involved SYK, ERK and JNK and activation of the transcription factors AP-1 and NFKB. Interestingly, $\beta$-glucan had no effect on antibody production or proliferation suggesting that $\beta$-glucans induce a different response than TLR-9 agonist $\mathrm{CpG}$ oligodeoxynucleotide $(\mathrm{CpG})$ that is a bacterial and viral DNA component known to induce cytokine production in B lymphocytes (Ali et al., 2015).

Glucans Increase gene Transcription in Murine (Mouse) Immune Cells

Treatment of murine Myeloid-Derived Suppressor Cells (MDSCs) with whole $\beta$-glucan particles was shown to increase the expression of Runx1, a transcription factor that induces differentiation in Myeloid-Derived Suppressor Cells (MDSC) and $m m u-$ miR-181d in M-MDSCs (downregulated in G-MDSCs) (Tian et al., 2015). These authors did not examine the function of miR-181d and a search in PubMed revealed no studies examining miR-181d in MDSCs. miR-181d is a stress-responsive miRNA in thymocytes with expression decreasing in response to LPS (Belkaya and van Oers, 2014). A search of microRNA.org revealed 8084 targets for has-miR-181d, but the role of increased miR-181d in response to $\beta$-glucan in MDSCs remains to be defined.

Treatment of murine bone marrow derived DCs with Whole $\beta$-Glucan Particles (WGPs) rapidly activated the dectin-1 receptor, increased SYK phosphorylation (10$20 \mathrm{~min}$ ) and increased cell surface GITRL protein (RNFSF 18) levels measured $48 \mathrm{~h}$ later (Tian et al., 2012). GIRTL (also called TL6) is a cytokine member of the TNF ligand family. GIRTL primes cytotoxic $T$ lymphocyte responses and downregulates the suppressive activity of regulatory $\mathrm{T}$ cells, thus inhibiting tumor progression in the mouse Lewis Lung Carcinoma (LLC) cell model (Tian et al., 2012). The authors also showed that treatment of mice implanted with LLC tumor cells with WBPs resulted in an increase in GITRL on DCs in vivo and slower tumor development.

Time course experiments in murine macrophagederived RAW264.7 cells showed that $\beta$ (1->3),(1->6)-Dglucan, purified from Aureobasidium pullulan, strongly upregulated the inflammatory cytokines IL-1 $\beta$ and IL-6 and weakly upregulated TNF $\alpha$. Increases in GM-CSF (CSF2) and G-CSF (CSF3), cytokines important for differentiation and proliferation, were also observed by 3 h with increased $D d x 58$ (RIG-1- retinoic acid inducible gene-1) and Mda5 (melanoma differentiation-associated protein 5) seen $6 \mathrm{~h}$ after treatment (Muramatsu et al., 2012). RIG-1 is necessary for Type I interferon production when cells are infected with a virus and MDA5 is an intracellular pattern recognition molecule for virus-derived RNAs which is necessary for Type I interferon production when cells are virus infected. These results correlate with the anti-viral activity of $\beta$ glucan observed in mice (Muramatsu et al., 2012).

Treatment of RAW264.7 mouse macrophage cells with $\beta$-glucan increased $\mathrm{TNF} \alpha$ and GM-CSF (granulocyte macrophage colony stimulating factor) after $3 \mathrm{~h}$. CSF2 is involved in the development and differentiation of lymphocytes from stem cells increased at $3 \mathrm{~h}$ and remained upregulated through $24 \mathrm{~h}$.

\section{$\beta$-Glucan Regulates Genes in a Human Tumor Cell Xenograft}

Treatment of female athymic mice with lentinan (LNT, Glc(b1-3)[Glc(b1-6)]Glc(b1-3)Glc(b1- 
3)Glc(b1-3)[Glc(b1-6)]b-Glc,

https://pubchem.ncbi.nlm.nih.gov/compound/37723) purified from Lentinusedodes (Shiitake mushroom) at a dose of $1 \mathrm{mg} / \mathrm{kg} /$ day $2 \mathrm{X} /$ week for 3 weeks reduced growth of xenografted human KB cells (a subclone of HeLa cells) (Harada et al., 2010). The KB tumors showed reduced expression of UMPS (Uridine monophosphate synthetase, also called Orotate Phosphoribosyl Transferase (OPRT)) at both mRNA and protein levels (Harada et al., 2010). Co-treatment with lentinan and S-1, an oral anticancer drug, increased upregulation of UMPS. Inhibition of UMPS would inhibit pyrimidine biosynthesis and thus inhibit nucleic acid biosynthesis, correlating with the antitumor activity of lentinan (Ina et al., 2013). The authors suggested that since lower levels of expression of OPRT has been associated with resistance to 5-FU based chemotherapies, cotreatment with lentinan may increase the successful use of therapeutic drugs such as S-1 and other 5-FU based chemotherapies.

\section{Genes Inhibited by $\beta$-Glucan}

A number of studies have identified genes whose expression is decreased by $\beta$-glucan treatment in human and mouse cells. Table 2 summarizes the information on these genes that have been identified. First, the results in human cells will be reviewed followed by studies in mouse cells.

\section{$\beta$-Glucan Inhibits Gene Transcription in Breast Cancer Cells}

Early studies in MCF-7 cells showed that a $48 \mathrm{~h}$ treatment with $400 \mu \mathrm{g} \mathrm{mL}^{-1}$ PCM3-II, a water-soluble $\beta$-glucan, inhibited cell viability and coordinately reduced Cyclin D1 and Cyclin E protein expression (Zhang et al., 2006). However, that study did not examine the impact of PCM3-II on gene transcription. We examined the effect of two concentrations of $\beta$-Dglucan on the expression of a set of genes implicated in breast cancer in MCF-7 and LCC9 cells using a PCR array. We reported that $\beta$-D-glucan inhibited the expression of cell proliferation and differentiation markers in MCF-7 cells, e.g., CDKN1C, CTNNB1, ERBB2, MUC1 and RARB (Jafaar et al., 2014). These changes in gene expression correspond to the observation that $\beta$-D-glucan dissolved in DMSO, but not water, inhibits MCF-7 cell proliferation (Jafaar et al., 2014). $\beta$-D-glucan also inhibited the expression of CDKN1C and CTNNBIin LCC9 cells (Jafaar et al., 2014). The mechanism(s) for these effects in MCF-7 and LCC9 cells has not been examined.

\section{$\beta$-Glucan Inhibits ERCC5 Expression in HepG2 Cells}

Treatment of HepG2 human hepatoma cells with a $\beta$-glucan-containing polysaccharide complex purified from Agaricusblazei (Murill mushroom of Brazilian origin) by aqueous extraction (Gonzaga et al., 2005) had no effect on cell viability (MTT assay), CYP1A1 or $C A S P 9$ gene transcript levels, but inhibited ERCC5 expression (da Silva et al., 2013). ERCC5 is involved in excision repair following DNA damage, but the authors did not pursue this finding. Interestingly, $\beta$ glucan treatment of HepG2 cells increased metabolites involved in bioenergetic metabolism, including alanine, glutamate and creatine. From these studies, the authors concluded that $\beta$-glucan increases metabolites needed for high energy metabolism and stimulates bioenergetics (da Silva et al., 2013). Interestingly, injection of yellow croaker (Pseudosciaenacrocea) fish with $\beta$-glucan $\left(5 \mathrm{mg} \mathrm{kg}^{-1}\right.$ body weight, from Sigma) $6 \mathrm{~h}$ prior to hypoxic stress inhibited reactive oxygen formation in the liver and increased transcription of Pyruvate Kinase (PK) while reducing F-ATPase, Succinate Dehydrogenase (SDH) and Malate Dehydrogenase (MDH) expression (Zeng et al., 2016). Which subunit of SDH or form of MDH was examined by PCR was not indicated. These results suggest that $\beta$-glucan inhibits the TCA cycle and enhances glycolysis in vivo in the liver of yellow croaker fish, although direct examination of TCA cycle metabolites, oxygen consumption or ATP production was not performed.

\section{$\beta$-Glucan Inhibits miR-9 Expression in Mouse Macrophage Cells}

A microRNA microarray in Whole $\beta$-Glucan Particles (WGP)-treated MDSCs isolated from the spleen of Lewis lung carcinoma bearing mice identified 61 miRNAs that were downregulated whereas 40 miRNAs were upregulated (Tian et al., 2015). Specifically, the authors identified miR-9 as an important regulator of Runx1 (runt-related transcription factor) as a direct, bona fide target of miR-9 (verified by 3'UTR luciferase reporter assay in HEK-293T cells). They also reported a decrease in Creb transcript levels in WGP-treated MDSCs, identified a binding site for CREB in the miR-9 promoter region and verified CREB suppression by a promoter luciferase reporter assay. Both CREB and mi-RNA suppression by WGP were shown to be mediated by the Dectin-1 pathway. These results support the conclusion that through the Dectin-1 
receptor, CREB directly regulates miR-9 expression in response to $\beta$-glucan. The downregulation of miR-9 results in an increase in Runx1 allows for differentiation, decreased immunosuppressive function and reduced tumor growth (Tian et al., 2015).

\section{$\beta$-Glucan Inhibits Proteins that Regulate Nucleic} Acid Synthesis in a Human Tumor Cell Xenograft

As reviewed above, treatment of female athymic mice with lentinan at a dose of $1 \mathrm{mg} / \mathrm{kg} / \mathrm{day} 2 \mathrm{X} /$ week for 3 weeks reduced xenograft human KB cell tumors (Harada et al., 2010). The authors reported reduced thymidylate synthase and dihydropyrimidine dehydrogenase proteins in the $\mathrm{KB}$ xenografts, results that correlated with inhibition of $\mathrm{KB}$ xenograft growth in vivo (Harada et al., 2010).

As discussed above, gene array profiling of human monocyte-derived DCs treated with a PS-G identified 4418 (19\%) probe sets downregulated (2-fold) after $16 \mathrm{~h}$ of treatment (Lin et al., 2006). The identity of downregulated genes included in the text of that manuscript (Lin et al., 2006) is shown in Table 2. The authors suggested that the decrease in ARHGDIB, ATM, CEBPA, CSFIR, CST, F13A1, ITGAM and ITGB2 transcripts after PS-G treatment may play a role in the anti-tumor activity of $\beta$-glucans (Lin et al., 2006). Another microarray profiling of human monocytederived DCs treated with $\beta$-D glucan $\left(10 \mu \mathrm{g} \mathrm{mL}^{-1}\right)$ for 4 or $12 \mathrm{~h}$ identified $\sim 1500$ genes that were either inhibited $(38 \%)$ or induced $(62 \%)$ (Cardone et al., 2014). The authors focused on upregulated transcripts and none of the downregulated genes were described; thus, these are not included in Table 2.

\section{Conclusion}

From the genes identified as regulated by $\beta$-glucan in this review, it is clear that $\beta$-glucan regulates the transcription of numerous immunomodulatory genes in human and mouse dendritic and macrophage cells. In addition, gene expression changes in response to $\beta$ glucans have been identified in human breast, gastric and liver cancer cells as well as a few other cell lines as summarized in Table 1 and 2. Figure 1 is a model of the generalized pathway by which $\beta$-glucan regulates gene transcription by interaction with a plasma membrane receptor which then activates an intracellular pathways leading to activation or inhibition of transcription factor activity. The activated transcription factors then regulate the transcription of cell-specific target genes.

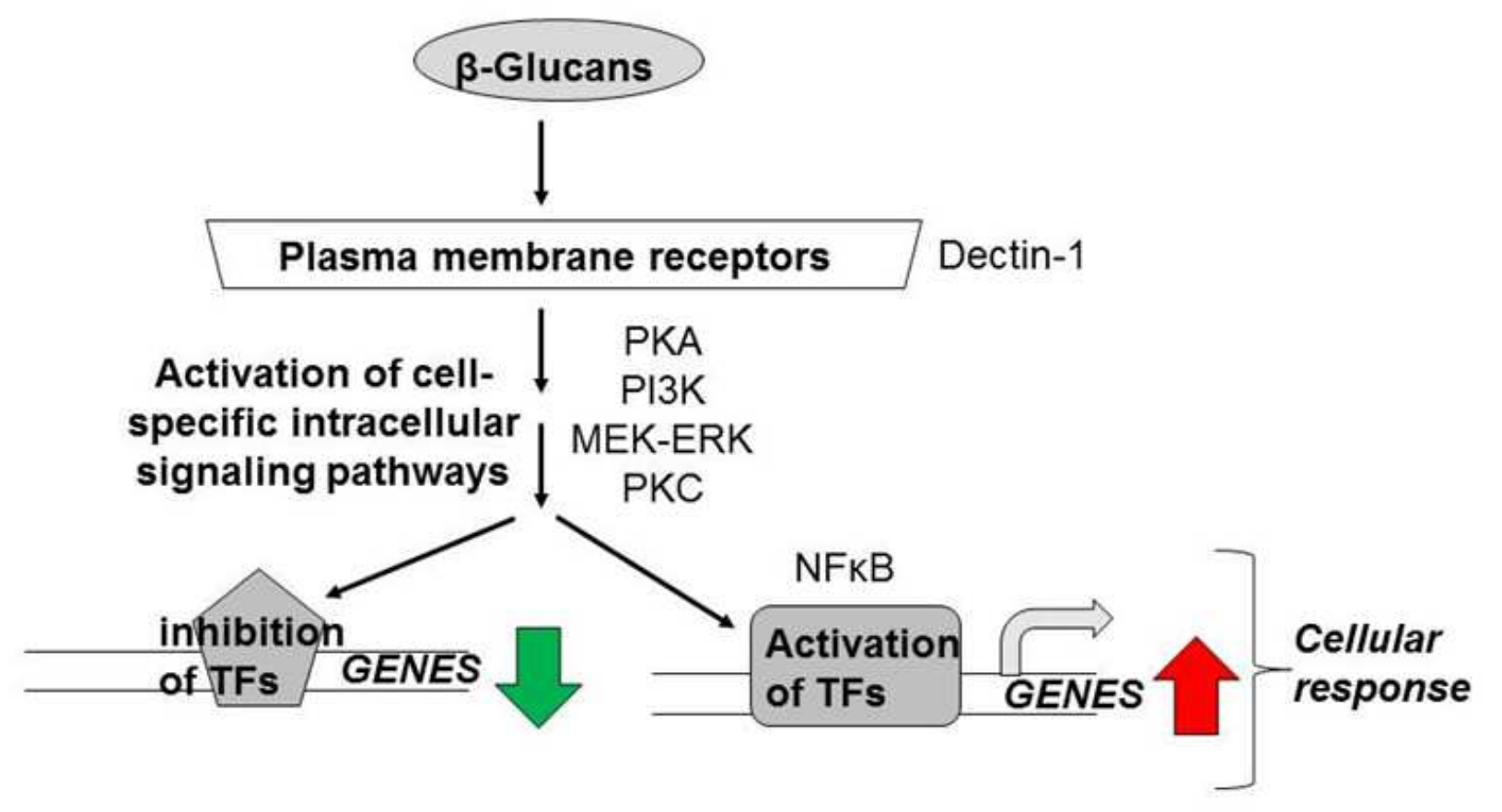

Fig. 1. General model of $\beta$-glucan regulation of gene transcription. Examples of cell type specific receptors, pathways and transcription factors are in plain font 


\section{Authors Contributions}

$\mathrm{MOH}$ and CMK contributed equally to the writing of this review.

\section{Conflict of Interest}

The authors declare no conflict of interest.

\section{References}

Aleem, E., 2013. $\beta$-Glucans and their applications in cancer therapy: Focus on human studies. Anticancer Agents Med. Chem., 13: 709-719. DOI: $10.2174 / 1871520611313050005$

Ali, M.F., C.B. Driscoll, P.R. Walters, A.H. Limper and E.M. Carmona, 2015. Beta-glucan-activated human B lymphocytes participate in innate immune responses by releasing proinflammatory cytokines and stimulating neutrophil chemotaxis. J. Immunol., 195: 5318-5326.

DOI: $10.4049 /$ jimmunol.1500559

Belkaya, S. and N.S.C. van Oers, 2014. Transgenic expression of MicroRNA-181d augments the stresssensitivity of $\mathrm{CD}^{+} \mathrm{CD}^{+}$thymocytes. PLoS One, 9: e85274-e85274.

DOI: 10.1371/journal.pone.0085274

Tian, J., J. Ma, K. Ma, B. Ma and X. Tang et al., 2012. Up-regulation of GITRL on dendritic cells by WGP improves anti-tumor immunity in murine Lewis lung carcinoma. PLoS One, 7: e46936-e46936. DOI: 10.1371/journal.pone.0046936

Bohn, J.A. and J.N. BeMiller, 1995. $(1 \rightarrow 3)-\beta-d-G l u c a n s$ as biological response modifiers: A review of structure-functional activity relationships. Carbohydr. Pol., 28: 3-14. DOI: $10.1016 / 0144-8617(95) 00076-3$

Chan, G., W. Chan and D. Sze, 2009. The effects of $\beta$ glucan on human immune and cancer cells. J. Hematol. Oncol., 2: 25-25. DOI: $10.1186 / 1756-8722-2-25$

Cardone, M., A.K. Dzutsev, H. Li, N. Riteau and F. Gerosa, et al., 2014. Interleukin-1 and interferon$\gamma$ orchestrate $\beta$-glucan-activated human dendritic cell programming viaI $\kappa \mathrm{B}-\zeta$ modulation. PLoS One, 9: e114516-e114516.

DOI: 10.1371/journal.pone.0114516

da Silva, A.F., D. Sartori, F.C. Macedo, L.R. Ribeiro and M.H. Fungaro et al., 2013. Effects of $\beta$ glucan extracted from Agaricus blazei on the expression of ERCC5, CASP9 and CYP1A1 genes and metabolic profile in HepG2 cells. Hum. Exp. Toxicol., 32: 647-654.

DOI: $10.1177 / 0960327112468173$
Gerosa, F., B. Baldani-Guerra, L.A. Lyakh, G. Batoni and S. Esin et al., 2008. Differential regulation of interleukin 12 and interleukin 23 production in human dendritic cells. J. Exp. Med., 205: 1447-1461. DOI: $10.1084 /$ jem.20071450

Gonzaga, M.L.C., N.M.P.S. Ricardo, F. Heatley and S.D.A. Soares, 2005. Isolation and characterization of polysaccharides from Agaricus blazei Murill. Carbohydr. Pol., 60: 43-49.

DOI: 10.1016/j.carbpol.2004.11.022

Harada, K., Y. Itashiki, T. Takenawa and Y. Ueyama, 2010. Effects of lentinan alone and in combination with fluoropyrimidine anticancer agent on growth of human oral squamous cell carcinoma in vitro and in vivo. Int. J. Oncol., 37: 623-631.

DOI: $10.3892 /$ ijo 00000711

Harnack, U., U. Kellermann and G. Pecher, 2011. Yeastderived beta-(1-3),(1-6)-D-glucan induces upregulation of CD86 on dectin-1-positive human Blymphoma cell lines. Anticancer Res., 31: 4195-4199. PMID: 22199280

Ina, K., T. Kataoka and T. Ando, 2013. The use of lentinan for treating gastric cancer. Anticancer Agents Med. Chem., 13: 681-688. DOI: $10.2174 / 1871520611313050002$

Jafaar, Z.M., L.M. Litchfield, M.M. Ivanova, B.N. Radde and N. Al-Rayyan et al., 2014. Beta-D-glucan inhibits endocrine-resistant breast cancer cell proliferation and alters gene expression. Int. J. Oncol., 44: 1365-1375. DOI: 10.3892/ijo.2014.2294

Kim, H.S., J.T. Hong, Y. Kim and S.B. Han, 2011. Stimulatory effect of $\beta$-glucans on immune cells. Immune Netw., 11: 191-195. DOI: 10.4110/in.2011.11.4.191

Kufe, D.W., 2013. MUC1-C oncoprotein as a target in breast cancer: Activation of signaling pathways and therapeutic approaches. Oncogene, 32: 1073-1081. DOI: $10.1038 /$ onc. 2012.158

Legentil, L., F. Paris, C. Ballet, S. Trouvelot and X. Daire et al., 2015. Molecular interactions of $\beta$-(1->3)-glucans with their receptors. Molecules, 20: 9745-9766. DOI: 10.3390/molecules20069745

Li, B., Y. Cai, C. Qi, R. Hansen and C. Ding et al., 2010. Orally administered particulate $\beta$-glucan modulates tumor-capturing dendritic cells and improves antitumor t-cell responses in cancer. Clin. Canc Res., 16: 5153-5164. DOI: 10.1158/1078-0432.CCR-10-0820

Lin, Y.L., S.S. Lee, S.M. Hou and B.L. Chiang, 2006. Polysaccharide purified from Ganoderma lucidum induces gene expression changes in human dendritic cells and promotes $\mathrm{T}$ helper 1 immune response in BALB/c mice. Mol. Pharmacol., 70: 637-644. DOI: $10.1124 / \mathrm{mol} .106 .022327$ 
Litchfield, L.M., S.N. Appana and C.M. Klinge, 2014. COUP-TFII inhibits NFkappaB activation in endocrine-resistant breast cancer cells. Mol. Cell Endocrinol., 382: 358-367.

DOI: $10.1016 /$ j.mce.2013.10.010

Lyakh, L., G. Trinchieri, L. Provezza, G. Carra and F. Gerosa, 2008. Regulation of interleukin12/interleukin-23 production and the T-helper 17 response in humans. Immunol. Rev., 226: 112-131. DOI: $10.1111 /$ j.1600-065X.2008.00700.x

Muramatsu, D., A. Iwai, S. Aoki, H. Uchiyama and K. Kawata et al., 2012. $\beta$-Glucan derived from Aureobasidium pullulans is effective for the prevention of influenza in mice. PLoS One, 7: e41399-e41399. DOI: 10.1371/journal.pone.0041399

Novak, M. and V. Vetvicka, 2008. $\beta$-glucans, history and the present: Immunomodulatory aspects and mechanisms of action. J. Immunotoxicol., 5: 47-57. DOI: 10.1080/15476910802019045

Queiroz, E.A.I.F., Z.B. Fortes, M.A.A. da Cunha, A.M. Barbosa and N. Khaper et al., 2015. Antiproliferative and pro-apoptotic effects of three fungal exocellular $\beta$-glucans in MCF-7 breast cancer cells is mediated by oxidative stress, AMP-Activated Protein Kinase (AMPK) and the Forkhead transcription factor, FOXO3a. Int. J. Biochem. Cell Biol., 67: 14-24. DOI: $10.1016 /$ j.biocel.2015.08.003

Rodríguez, M., E. Domingo, S. Alonso, J.G. Frade and J. Eiros et al., 2014. The unfolded protein response and the phosphorylations of activating transcription factor 2 in the trans-activation of il23a promoter produced by $\beta$-glucans. J. Biol. Chem., 289: 22942-22957. DOI: 10.1074/jbc.M113.522656

Ross, G.D., 2000. Regulation of the adhesion versus cytotoxic functions of the Mac-1/CR3/alphaMbeta2integrin glycoprotein. Crit. Rev. Immunol., 20: 197-222. PMID: 10968371
Saraswat-Ohri, S., A. Vashishta, V. Vetvicka, K. Descroix and F. Jamois et al., 2011. Biological properties of $(1 \rightarrow 3)-\beta$-d-Glucan-based oligosaccharides. J. Med. Food, 14: 369-376. DOI: $10.1089 /$ jmf.2010.0081

Tanaka, K., Y. Tanaka, T. Suzuki and T. Mizushima, 2011. Protective effect of $\beta-(1,3 \rightarrow 1,6)$-d-glucan against irritant-induced gastric lesions. Br. J. Nutr., 106: 475-485. DOI: $10.1017 / \mathrm{S} 0007114511000365$

Tian, J., K. Rui, X. Tang, J. Ma and Y. Wang et al., 2015. MicroRNA-9 regulates the differentiation and function of myeloid-derived suppressor cells via targeting Runx1. J. Immunol., 195: 1301-1311. DOI: $10.4049 /$ jimmunol.1500209

Vetvicka, V., S. Saraswat-Ohri, A. Vashishta, K. Descroix and F. Jamois et al., 2011. New 4-deoxy-(1 $\rightarrow 3)-\beta$ d-glucan-based oligosaccharides and their immunostimulating potential. Carbohydr. Res., 346: 2213-2221. DOI: 10.1016/j.carres.2011.06.020

Wang, W.J., Y.S. Wu, S. Chen, C.F. Liu and S.N. Chen, 2015. Mushroom beta-glucan may immunomodulate the tumor-associated macrophages in the Lewis lung carcinoma. Biomed. Res. Int., 2015: 604385-604385. DOI: $10.1155 / 2015 / 604385$

Zeng, L., Y.H. Wang, C.X. Ai, J.L. Zheng, C.W. Wu et al., 2016. Effects of $\beta$-glucan on ROS production and energy metabolism in yellow croaker (Pseudosciaena crocea) under acute hypoxic stress, Fish Physiol. Biochem., 42: 1395-1405. DOI: $10.1007 / \mathrm{s} 10695-016-0227-1$

Zhang, M., L.C. Chiu, P.C. Cheung and V.E. Ooi, 2006. Growth-inhibitory effects of a beta-glucan from the mycelium of Poria cocos on human breast carcinoma MCF-7 cells: Cell-cycle arrest and apoptosis induction. Oncol. Rep., 15: 637-643. PMID: 16465424 